\title{
1. Changing regulatory arrangements in food governance
}

\section{Tetty Havinga, Donal Casey and Frans van Waarden}

\subsection{INTRODUCTION AND SUMMARY}

The leading position of nation states in food regulation has been displaced by novel, fragmented and complex patterns of regulatory arrangements. Global food governance and regulation is increasingly the activity of not only national governmental actors, but also of a multitude and diversity of private actors and international organizations. Governmental food regulation has come under pressure. While on the one hand the limited capacity of state institutions in this policy sphere has become visible, there has on the other hand been a concomitant increase in the requirements of and expectations towards the state to regulate food safety and quality. Complex global food supply chains and the perception of insufficient governmental regulation point to the limitations of governmental food regulation. The growing public concern about food safety, new concerns about lifestyle risks, animal welfare, sustainability, and advances in scientific and technological capabilities have led to rising expectations of governmental food regulation. Responses of both public and private organizations to current challenges have resulted in a new landscape of food governance.

In this landscape we can observe a distinct shift from the national to the international governmental level and from public to private governance. The European Union has attempted to strengthen its food safety legislation with the establishment of the European Food Safety Authority. Furthermore, private actors took a leading role in global food safety regulation and the development of retail driven food safety regulation from the 1990s onwards. Both transitions resulted in fragmented and complex regulatory arrangements with a multiplicity of actors at multiple levels.

The new attention to food regulation provides an opportunity to investigate a number of broader issues that have concerned regulatory governance scholars. These issues include: (i) the legitimacy, effectiveness 
and consequences of public and private regulation; (ii) the interaction of both layers and networks of regulation; (iii) regulatory responses to crisis and contestation; and (iv) the distribution of power in regulatory arrangements. It is against this backdrop that this collection of chapters is set.

In this introduction we outline the major trends in the food supply chain and the expectations regarding adequate regulation and control of food. These developments constitute the background of changing regulatory arrangements in food governance. After that we provide a rough sketch of the responses of both governmental agencies and private parties to these developments. Finally the chapters in this volume are introduced.

\subsection{DEVELOPMENTS RELATED TO THE FOOD SUPPLY CHAIN}

Recent decades have seen new major developments, that have produced radically different challenges as well as opportunities for food quality and safety. These trends have on the one hand provided new hitherto unheard of opportunities for food adulteration and created new types of risks and uncertainties for food consumers, raising the expectations of citizens towards their governments to protect them from such risks. Such trends have also produced new opportunities for judging, monitoring, and improving quality and safety, both ex ante in production itself as well as ex post through new forms of regulation and oversight. These have raised the expectations of citizens further: whatever can technically be done to improve food safety, quality, and oversight, should be done. On the other hand there have been trends that have reduced the capacity of national governments to satisfy these raised expectations of their citizens. What are some of these major trends?

\subsubsection{New Products and New Modes of Production}

Each day new food products are launched on the market. In some cases it is merely a new package or a new name for an already existing product. In other cases new ingredients are added, new recipes are used or entirely new products are developed. Many food products are processed foods. Less than half of the food people in the US, Spain and France eat is unprocessed basic food such as vegetables, fruits and meat. ${ }^{1}$ Even fresh vegetables, fruits, seafood and meat are increasingly bought ready-to-eat (washed, cut, spiced, pre-cooked, preserved, and mixed).

Consumers can value the freshness of fish or the looks of apples and 
tomatoes; but the quality and freshness of composed food products is more difficult to value. Consumers often do not know how their food is being produced. Which chemicals have been added and which conservation methods are used (radiation, pasteurization, heating), and what risks might be involved? Processed foods are also more vulnerable to fraud, in particular in cases where the fraud is not easily noticed by the consumer, for example when replacing an expensive ingredient with a cheap one (horsemeat in lasagna) or omitting costly process prescriptions (misrepresenting regular meat as halal or organic).

\subsubsection{Complex Global Food Value Chains}

The food supply chain has become more internationalized and much longer and the share of composed foods with ingredients from all over the world has increased. We can see the scale and geographies of commerce globalizing and expanding beyond the nation state. Like many other issue areas and systems of production, the past twenty years have witnessed the rapid 'globalization of the agri-food system' (Hatanaka et al. 2005). Products come to us from everywhere around the globe. This concerns not only processed food, but also fresh products. In response to consumer demand, improved techniques for transport and storage, and growing consumer incomes, European retailers increasingly obtain fresh products from all over the world enabling a year-round supply. The food chain encompasses places of production and trading around the globe. In a local supermarket in the Netherlands or the UK, you will find mangos from Mali, salmon from Scotland, avocados from South Africa, shrimps from Thailand and French beans from Kenya next to domestic produced foods.

Ingredients in processed foods are not just locally obtained, but are sourced from all over the world. The incident involving milk contaminated with melamine from China in 2008 illustrates the consequence of global sourcing of food ingredients. Melamine was found worldwide in various food products: in sweets, cookies, chocolate, baby food, pretzels, icecream, coffee and soya in countries such as Singapore, Indonesia, Canada, the United States, the Netherlands, the United Kingdom and Poland. These products were probably produced with an ingredient that contained contaminated Chinese milk. ${ }^{2}$

The global sourcing of food creates new types of risks within the supply chain 'as food is subject to greater transformation and transportation, and fragmented supply chains across multiple enterprises and food production systems with diverse producer characteristics, regulatory frameworks, environmental conditions and technical expertise are brought together' (Henson and Humphrey 2010). Such complex global food supply chains 
make things difficult for governmental agencies aiming at the production and marketing of safe food. This applies particularly to national governments without jurisdiction outside their national borders. They can only rely on inspections by foreign agencies (governmental or private) and import controls (see Constant Laforce in this volume).

\subsubsection{Advances in Science and Technology}

Scientific advances are important in food governance in several respects and give us more scientific knowledge about risks, food safety, and (un) healthiness of food ingredients and food habits. New technological knowledge results in new ways to produce, store, conserve, pack, transport and prepare food. New knowledge also results in more techniques to identify risks, substances and the authenticity of food, and new opportunities to manage and control identified risks. In food governance science plays an increasingly important role in risk assessment and risk management. International treaties from the $\mathrm{WHO}$ and the EU prescribe countries a science based food policy in order to avoid unfair competition, protectionism and trade barriers. Governments depend highly on external experts for scientific knowledge and risk assessment. Here, science has come to dictate in large part: (i) how food safety and quality standards are developed; (ii) who should develop them; (iii) what the contents of such rules should be; and (iv) how the standards should be enforced. Thus, there are important implications for not only the setting of standards, but also for the means of verification and implementation.

Monitoring and controlling food production processes and food products is highly dependent on technological devices and knowledge. Advances in scientific and technological capabilities to detect even small amounts of substances in food and the growing knowledge about diseases related to food add to the public perception of food safety risks. For example, the possibilities to connect information from different sources results in a higher level of detected food-borne diseases.

Modern information and communication technology provides many opportunities for worldwide easy and fast information exchange. This fosters the development of hypes: information or misinformation on the web can result in media coverage, consumer boycott or pressure on governments to take action.

Moreover, science is not only of instrumental value, but also of great normative value by providing constitutive and legitimating support to actors engaged in governance (Drori et al. 2002). Many commentators have observed the scientization of contemporary society through the expanded role played by science in many aspects of social, economic 
and political life. In particular, it has been noted that one of the most 'striking features of contemporary society is that science speaks with highly legitimate authority on the widest range of questions' (Drori and Meyer 2006a, 40). Importantly, the expanded authority of science is now also a central feature of contemporary governance. Indeed, the reliance upon science and scientific discourse as a base of legitimacy has taken a dominant role in the legitimating actions of actors engaged in governance to the extent that it has primacy over moral, political or pragmatic bases of legitimacy (Djelic and Sahlin-Anderson 2006, Drori and Meyer 2006). The expansion of scientific authority provides legitimating tools for actors as the knowledge assumed to be embedded in science provides justifications for political, economic, and social choices of actors. The reason for this lies in the perceived value neutrality of decisions and rules based upon science, and the fact that they emanate from experts. Political debates following the BSE crisis and the discussion around genetically modified foods have questioned the neutrality of scientific knowledge. However, while in many cases the perceived reliance on science and expert knowledge may only hold symbolic power, it still constitutes a significant institutional force (Jacobsson 2000, 40). Greater knowledge also brings new and extended responsibility of authorities. They cannot continue as if nothing has changed.

\subsubsection{New Perceptions of Food Safety}

What is regarded as safe food depends on available knowledge and hence changes over time. Due to the advances in science and technology we know more and more about food, risks, food-borne illness, allergens, and so on. Several risks may be connected to food: contamination with bacteria, prions or toxic material (animal pharmaceutical, herbicides, and dioxin), allergens and particular nutrients (sugar, fatty acids, unhealthy eating) (Van Kreyl and Knaap 2004, McCabe-Sellers and Beattie 2004). It is not always obvious which foods are safe for consumption. The same food may carry no risk at all for one consumer, and be quite dangerous for another consumer (due to allergic response, disease or eating habits). The ways food is stored and prepared can cause food disease or kill harmful microbes. Risks of using a particular production method or additives are not always known. There also might be a difference between subjective and objective risks.

Over time we see changes in what is considered to be the major food safety issue. Between 1970 and 1990 much attention was paid to harmful chemical substances in food. After 1990 healthy food became the most prominent issue. Recently the chemical safety of food is receiving attention 
once again, along with the health consequences of animal diseases and microbial contamination.

\subsubsection{Public Concern about Food}

Food scandals have regularly hit the media headlines. The 2013 horsemeat scandal concerned horsemeat being sold as beef or 'hidden' in meat products like hamburgers, sausages and lasagna. Around that time it was also discovered that some eggs were inaccurately claimed to be organically produced and in Germany frozen fish and seafood were made intentionally heavier by adding water. Some revelations were unfounded, such as the claim that Spanish firms had used the meat of abandoned cats and dogs in the production of animal feed and meatballs. Nevertheless they are reported in the media and result in consumer concern about adulteration and thus, the credibility of both the regulatory regime and food business operators.

More serious, however, are food incidents where human health is at risk. In 2011, a number of consumers became fatally ill as a result of the EHEC bacteria. It took some time before the source of the contamination was identified. Several raw vegetables notably cucumbers, tomatoes, lettuce, bean sprouts, and fenugreek from the Netherlands, Spain and Egypt were said to be the source of EHEC. This led several countries, including Russia, to close their borders to such products. In 2008, Chinese dairies added melamine to their milk in order to fraudulently increase the protein level of the milk (see Burns et al. in this volume). Six children died and 54000 children were hospitalized as a result of consuming the adulterated milk. The scandal also had some unforeseen consequences, as the demand in China for foreign baby milk formula created a shortage of it in the Netherlands in 2013.

The best known of such incidents in recent decades has been the BSE crisis. In order to introduce a cheap means of protein into the animal feed system, animal protein such as bone meal was added to the feed chain. This introduction resulted in a new disease in animals that was subsequently passed through the food chain to consumers. Between 1986 and 2009, 168 people, mostly in the UK, died from the variant CreutzfeldtJakob disease, a deadly brain disorder.

The 20 March 1996 statement by the then Conservative British government that there was a probable link between Bovine Spongiform Encephalopathy (BSE) and variant Creutzfeldt-Jakob (vCJD) disease created unprecedented widespread concern among consumers about the safety of their food and a new heightened awareness of food safety issues. ${ }^{3}$ This consumer concern permeated through Europe and has continued 
to do so in light of new manufactured risks such as genetically modified foodstuffs and pesticide residues. This transformation in the mind-set of European consumers has been linked by agricultural sociologist Hugh Campbell (2006: 126) to a broader shift in Western societies 'from politics of class (which has dominated modernity since the Industrial Revolution) to politics of risk' - a manifestation of Beck's 'risk society' (Beck 1992). As Moran $(2002,407)$ notes, "risk society" in turn produces a regulatory society'.

Traditional public concerns regarding food were focused on the availability of enough food (food security) and the absence of dangerous or unhealthy food (food safety). However, public concern about food is not confined to issues of safety and health risks. Consumer expectations, preferences and attitudes have changed in relation to food quality and increased recognition of the external effects of their consumption. There has been increased emphasis and importance attached to non-traditional quality attributes of food associated with the environmental, social and animal welfare dimensions of food production processes and the corollary effects consumption can have on these issues (Kysar 2004). Increasingly, claims are being made that food has been responsibly produced (sustainable food production, fair trade, animal welfare and labour rights) and is healthy (with less sugar, salt, fat, additives, and fewer calories). These new concerns about sustainability, health, animal welfare and the social effects of the globalization of food production, add new requirements to the food production and distribution system.

\subsection{DEVELOPMENTS RELATED TO GOVERNMENTAL REGULATION}

The last decades have seen a growing public concern about food. Better informed, critical and assertive consumers expect their government to secure safe and healthy food and protection against all risks. We could speak of a revolution of rising expectations: as food becomes safer and as knowledge about food risks increases, we expect an increased level of food safety, or even better, 100 per cent safety.

\subsubsection{Higher Expectations towards Public Authorities by their Public}

The growing public concern about food contributed to the call for more transparency and accountability. This normative pressure takes the form of promoting a model of food safety and quality regulation that provides structures and procedures within the standard setting, monitoring 
and enforcement activities that seek to advance transparency, openness, representation, participation, deliberation and consensus. For example, the new UK food safety structure offers opportunities for participation and a high level of transparency. Many food safety authorities make documents, inspection reports and so on available to the interested public. Private parties are also faced with comparative demands to provide more transparency, openness, participation, deliberation and consensus.

Food safety developed from a mainly technical and apolitical issue into a politically debated and contested issue. Food safety got heightened issue saliency after several food related scares and disputes, such as mad cow disease, hormone-treated meat, dioxin contamination, genetically modified foods, EHEC and the horsemeat scandal. Food risks became more visible and recognized and are the subject of growing public concern. Food safety issues attract media attention and are debated by political groups. This puts pressure on public authorities and the food industry to take adequate measures to prevent future scandals and to secure the safety of food. Loeber et al (2011) show that framing incidents as 'food scares' (in contrast to framing them as environmental scandals or disasters in the past) goes hand in hand with institutional changes in the regulatory system in the European Union and in several EU member states.

\subsubsection{With (Perceived) Limits to Government Regulation}

Moreover, the BSE crisis and subsequent food scares have led to a decline in the perceived ability of state governance systems to effectively regulate and guarantee the safety of food (Caduff and Bernauer 2006). The identification of new risks has also changed consumers' attitudes towards food safety, and more importantly has damaged the trust consumers have in state regulation. The response of the British government to the BSE crisis has often been cited as a manifest illustration of the inability of the national government to deal with food risks. The BSE crisis also showed that the European Union failed to act adequately (Vos 2000). The Commission had followed a policy of disinformation that had prevented legislative activity and member states from restricting the import of British beef. The relevant committees had been influenced by British members and were under political pressure. The BSE crisis counts as a turning point in the European Union's food policy. This criticism on the effectiveness of governmental food regulation corresponds with the general perception that traditional command-and-control regulation is ineffective, inflexible and neglects the responsibilities of corporations and citizens. Enticott and Lee (in this volume) present an example of governmental regulation that is counterproductive. They show that the UK compensation policies for 
animal diseases such as bovine tuberculosis and foot and mouth disease provide no incentive to develop best practices and precautionary measures.

Paradoxically, governments are confronted with higher expectations and demands regarding the safety, quality, and reliability of food products on markets, while the past decades have seen an increasing dominance of the neo-liberal ideology favouring a limited role for the government in society in general and markets in particular. Neo-liberalism advocates economic liberalism, free trade, open markets, the reduction of government regulation, cutting of public expenditures and a small public sector. Moreover, national states are also constrained by international law from the WTO and the EU. In international relations the fear for protectionism and unfair competition is an important impediment for national food regulators.

\subsection{THE RESULT: COMPLEX AND DIVERSE REGULATORY ARRANGEMENTS IN FOOD}

Trends in the food industry pose new challenges to government regulation of food quality and safety. The globalization of food chains implies that production and distribution are increasingly beyond the territorial jurisdiction of national governments. The increased popularity of composed foods implies that it is more difficult to identify their composition, origin and the conditions of production. Advances in science and technology have increased our understanding about risks, but the counter side is that with more knowledge comes more responsibilities for the prevention, aversion or correction of risks. Knowledge cannot be undone. That has fueled public expectations towards governmental protection: through public regulation and of course instantaneous, effective, and efficient implementation and enforcement. Yet these same citizens are also wary of 'too big government'.

In the context of these developments new forms of food governance have emerged, notably new European Union food law, private food standards, corporate social responsibility initiatives, and transnational regulation. The current landscape of food governance contains a growing diversity of regulatory arrangements: public, private and hybrid, on national, transnational and global levels.

In response to food crises, the decline in consumer confidence and the threat of losing export markets, the European Union strengthened its food safety legislation and established the European Food Safety Authority. The European Commission responded to the accusation of lack of transparency and of manipulation during the BSE crisis with proposals 
for radical reform. It adopted an approach emphasizing food safety and consumer protection based on three general principles:

1. separation of the responsibility for legislation and for scientific advice;

2. separation of the responsibility for legislation and for inspection; and

3. greater transparency and information during decision-making and inspection.

The 2002 General Food Law lays down the general principles and covers the entire food supply chain, including not only food safety requirements but also issues of animal health, product quality, cattle feed and sustainability. European directives are replaced by regulations; regulations are a more immediate and hence stronger legal form because they are directly applicable, i.e. they do not need transposition by member states in national legislation to become effective. ${ }^{4}$

Several European member states have established new regulatory agencies or reformed existing agencies to oversee the food control activities (see Abels and Kobusch in this volume). Likewise, the Chinese governmental agencies responded to several food crises, and their negative effects on the reputation of Chinese export products with legal reforms and other measures (Collins and Gottwald; Burns et al. in this volume).

Producers and suppliers have become primarily responsible for food safety, while national governments have become responsible for controlling the adequacy of risk controlling mechanisms of companies in the food chain. Because of their legal responsibility and out of fear for potential reputation damage due to food scandals caused by claims of unsafe or unfair food products, the food industry and retailers have developed initiatives for decreasing food safety risks and increasing consumer confidence in food products. In the 1990s several large food manufacturers and supermarket chains developed their own quality control systems. In order to control the input, the companies want to make sure that the goods they purchase will meet particular standards and qualifications. A company quality control system often includes requirements for suppliers. For example, in the 1990s several British and Dutch supermarket chains contractually obliged suppliers to meet a comprehensive quality assurance standard, including unexpected inspections at farms, gardens and plants (e.g. Albert Heijn (AH) in the Netherlands, Tesco and Sainsbury's in the United Kingdom) (Havinga and Jettinghoff 1999, Havinga 2006). Since the 1990s private retail standards have expanded dramatically. Food retailers joined forces to harmonize supplier standards. Regulation of food safety by retailers using quasi-legislation as an instrument to force trade partners to take food safety measures evolved from regulation that 
originated from one supermarket chain to regulation of the united supermarkets. These standards are often monitored by independent certification and inspection organizations. National private certification schemes have crossed borders and became global or transnational (Fuchs et al. 2011; Fagotto in this volume).

Retailers use their purchasing power to impose food safety and quality requirements, as well as other specific product and process preferences, on farmers and food industry suppliers. Given the ever growing size of these food retail chains, suppliers are dependent on them and have to comply with their requirements if they want to sell (Boselie et al. 2003; Grabosky 1994, 429-432; Havinga 2006; Marsden et al. 2000, 2010).

Next to retail driven standards many other private food standards have emerged, initiated and promoted by the food industry, trading corporations, trade associations and non-profit civil society organizations or NGOs. Their objectives range from securing safe food to improving animal welfare, protecting the environment, labour rights, or ensuring fair trade. Examples include fair trade labels, sustainability, religious food standards (see Van Waarden and Van Dalen in this volume), organic food labels, food safety, vegetarian or biodynamic labels (Van der Meulen 2011).

In these new forms of regulation, private actors are assuming pivotal roles in rule-making, monitoring compliance, and enforcement. The food industry, and retail corporations in particular, have become key players in the governance of the global food system through the creation of governance institutions such as private standards, corporate social responsibility initiatives (CSR) and public-private or private-private partnerships. Kalfagianni and Fuchs (in this volume) and Oosterveer (in this volume) investigate the source of legitimacy and accountability of these private forms of governance.

Recently hybrid governance forms have also been developed involving both governmental and private actors. This hybridisation has consequences for the conceptualisation of regulatory roles and forms of governance (Havinga in this volume). Cooperation between government and industry in food governance challenges the existing distribution of power and responsibilities (Van der Voort in this volume).

\subsection{AIM AND STRUCTURE OF THIS VOLUME}

This volume examines the changing new governance of food. The introductory part sketches the developments and institutional challenges in food governance and the new forms of food regulation that have been developed. Tetty Havinga argues that new private and mixed forms of 
food regulation ask for a rethinking of the relevant distinctions between the actors involved and the roles they play in the regulatory process. A regulatory regime performs five functions: (1) rule making; (2) adoption of the rules; (3) implementation of the rules; (4) monitoring compliance; and (5) enforcement. Havinga contends that the traditional distinctions between public and private actors, and between state, market and civil society actors, masks interdependence, conflicts of interest and power, and advocates a more detailed analysis.

Part II investigates public policy responses to the challenges posed by food crises, in particular in the European Union and its Member States, and in China. Gabriele Abels and Alexander Kobusch analyze the national institutional choices concerning independent food safety agencies in 23 out of the 27 EU Member States. In so doing, they question whether these choices can be explained by path dependency or rather as a phenomenon of Europeanization. Abels and Kobush classify food risk governance regimes in three organizational models:

1. the bi-institutional model (risk assessment separated from risk management);

2. the integrated model (one food authority is responsible for both risk assessment and risk management); and

3. a fragmented model (during period of transition).

Both Europeanization and national historical tradition are shown to have been important in Austria, Sweden and Hungary - these three countries each represent a specific organizational model of food risk governance.

Drawing on case law and reforms of animal health legislation, Gareth Enticott and Robert Lee analyse the way the United Kingdom deals with animal diseases. For Enticott and Lee, compensation provided by the state when diseased animals are slaughtered should incentivise good practice, deter illegal or inappropriate practices and provide a fair system. They conclude that the current UK compensation system provides limited incentive for bio-security and has led to some perverse effects.

The next two chapters shift the focus from the European Union to China. The Chinese food safety system is important from a European perspective because of China's significance as a trading partner with the European Union, and recent food scares such as milk tainted with melamine. Neil Collins and Jörn-Carsten Gottwald analyze the impact of the new Chinese Food Safety Law 2009 on Chinese regulatory practice. They examine four dimensions: (1) organization; (2) guiding principles; (3) configuration of actors; and (4) specific reform capacity. The authors examine how the pressures of local interests have been accommodated to the demands of 
globalized capitalism. Furthermore, Collins and Gottwald illustrate the changing nature of the relationship of the state and its regulations to the citizens of China, again sometimes by conceding, sometimes by coercing.

John Burns, Jing Li and Xiaoqi Wang's comparative study of the Chinese mainland and Taiwan's reaction to adulterated milk powder highlights that politicians make institutional choices for the delivery of public services, including the regulation of food safety, based on the incentive systems through which they operate. On the mainland an incentive system that rewards officials for fulfilling a narrow range of targets has had the unintended consequence that they relatively ignore non-targeted policy goals. Pressure for food safety reform has probably come mostly from China's external trade partners. In Taiwan local officials are also looking up to their bureaucratic principals but the incentive system of competitive elections in a system with media freedom and a well developed civil society means that the public as principal is also important. Public disgust with the handling of a food safety crisis opened a window for administrative reform that could improve policy coordination through centralization.

Part III deals with new forms of private food governance. Peter Oosterveer investigates whether the theoretical frameworks of Sassen and Rosenau might enable us to better understand (environmental) authority in the global governance of food, and in particular, the balance that should be established between the public and the private sphere. Using the cases of two private food standards (GlobalG.A.P. and Marine Stewardship Council [MSC]), Oosterveer concludes that these standards do not derive their authority and legitimacy from formal procedures but from intended output. The case of MSC shows that a private standard is capable of including countervailing power within the regulatory arrangement. Developing upon Sassen and Rosenau, Oosterveer points to the role of science in food governance.

Effectiveness is a crucial criterion for the legitimacy of private forms of governance as it is frequently identified as private actors' claim to legitimacy. In their analysis of the effectiveness of GlobalG.A.P. in fostering sustainable development, Agni Kalfagianni and Doris Fuchs focus on the stringency of the GlobalG.A.P. standard. They argue that effectiveness is a function of external pressure, internal collaborative structures, and characteristics of available solutions, as well as the size and heterogeneity of the group of actors designing and implementing the governance institution. They expect that a 'larger degree of decision-making power of environmental and social NGOs in the GlobalG.A.P. governance mechanisms would likely have led to a different outcome (more stringency)'.

Federica Casarosa and Marco Gobbato analyze private quality standards operating in interfirm networks in the wine sector. Based on 
questionnaires answered by enterprises and institutional actors in five European countries, several models of networks, built by companies to achieve quality, are distinguished. While standard setting seems less costly in contractual networks compared to organizational networks, implementation may be more difficult in a contractual network.

Frans van Waarden and Robin van Dalen characterize the market for halal certificates in the Netherlands as a case of complex (proto)regulation in a liberalized market where increasingly a need for regulation is being felt. In the absence of any public regulation there have been multiple private initiatives for halal quality regulation in the form of organizations offering halal certification and halal hallmarks. However, consumers do not know how to value these halal certificates, the market is opaque, and a supreme authority seems to be required.

Part IV deals with situations of both public and private governance and investigates their interaction. Taking a law and economics approach, Elena Fagotto explores whether transnational private food safety arrangements complement or compete with public food safety regulation. She argues that private actors have significant incentives to achieve food safety, and that there is a strong alignment of public and private interests in providing safe food. As such, private food safety arrangements could offer a solution for known weaknesses of public regulation, namely institutional fragmentation, international dimension and insufficient enforcement capacity. Nevertheless, Fagotto warns not to replace public with private regulation given the shortcomings in the enforcement of private regulation by third party certification bodies.

Developing countries' exports are affected by food safety regulations and standards imposed by both EU governmental and non-governmental actors, such as those imposed by retailers. Vanessa Constant Laforce analyzes, from a legal perspective, the nexus between these two forms of food safety requirements, with a particular focus on pesticides. The export of tropical fruits from developing countries to the EU has largely increased during the last decade. SPS requirements and pesticide residues levels are the major trade obstacles for developing countries' opportunities to access the EU market. Private standards such as GlobalG.A.P. exceed official import requirements and are widely criticized by developing countries because they are significant barriers to their export.

The last chapter is a case study of a hybrid form of food governance. Haiko van der Voort analyzes an attempt of the Dutch government to incorporate private regulation. Van der Voort utilises the concept of 'metagovernance' to analyze change in a co-regulation regime on safeguarding the quality of Dutch eggs. Van der Voort sketches two perspectives on metagovernance: (i) metagovernance as design; and (ii) metagovernance as 
management. The Dutch Ministry of Agriculture has adopted an elaborate policy framework that describes institutional requirements for cooperation with industries and their self regulatory bodies, stressing the final responsibility of the government for the quality of the regulations and oversight. The egg quality system of the poultry sector was brought under this regime. Actors from the industry, the government and the certification industry were involved in this regulatory arrangement.

\section{NOTES}

1. New York Times, http://graphics8.nytimes.com/images/2010/04/04/business/04metrics_g/ 04metrics_g-popup-v2.jpg (last accessed 23 May 2012). In 2009, people in the US consumed 787 pounds per capita packaged food and 602 pounds fresh food; in Spain, 759 pounds packaged and 621 pounds fresh food; and in France, 739 pounds packaged and 462 pounds fresh food.

2. Kennisbank Voedselveiligheid VWA, Melamine, www.vwa.nl; David Bradley, Melamine contaminated food list, http://www.sciencebase.com/science-blog/melaminecontaminated-food-list.html; http://www.niernieuws.nl/?id=1747\&cat =\&loc =5\#; http:// evmi.nl/voedselveiligheid-kwaliteit/melamine-duikt-op-in-pindakoek/; http://evmi.nl/vo edselveiligheid-kwaliteit/ah-waarschuwt-voor-melamine-zoutjes/ (all documents accessed 9 May 2012).

3. BBC, 'BSE and CJD: Crisis Chronology', http://news.bbc.co.uk/hi/english/static/in_ depth/health/2000/bse/1996.stm, accessed 28 May 2012.

4. Regulation (EC) No 178/2002 of the European Parliament and of the Council laying down the general principles and requirements of food law, establishing the European Food Safety Authority and laying down procedures in matters of food safety (also referred to as the General Food Law). The three basic EU food hygiene regulations are: Regulation (EC) 852/2004 on the hygiene of foodstuffs, Regulation (EC) 853/2004 laying down specific hygiene rules for food of animal origin, and Regulation (EC) 854/2004 laying down specific rules for the organization of official controls on products of animal origin intended for human consumption.

\section{REFERENCES}

Beck, U. (1992), Risk Society. Towards a New Modernity, London: Sage Publications.

Beckert, J. and P. Aspers (eds) (2011), The Worth of Goods. Valuation and Pricing in the Economy, Oxford: Oxford University Press.

Boselie, D., S. Henson and D. Weatherspoon (2003), 'Supermarket Procurement Practices in Developing Countries: Redefining the Roles of the Public and Private Sectors', American Journal of Agricultural Economics, 85, 1155-1161.

Caduff, L. and T. Bernauer (2006), 'Managing Risk and Regulation in European Food Safety Governance', Review of Policy Research, 23, 153.

Campbell, H. (2006), 'Consultation, Commerce and Contemporary Agri-Food Systems: Ethical Engagement of New Systems of Governance under Reflexive Modernity', The Integrated Assessment Journal, 6, 117, 126.

Djelic, M-L. and K. Sahlin-Anderson (2006), 'Introduction: A World of 
Governance: The Rise of Transnational Regulation', in M-L. Djelic and K. Sahlin-Anderson (eds), Transnational Governance: Institutional Dynamics of Regulation, Cambridge: Cambridge University Press, pp. 1-28.

Drori, G. et al. (2002), Science in the Modern World Polity: Institutionalization and Globalization, Redwood City: Stanford University Press.

Drori, G.S. and J.W. Meyer (2006), 'Scientization: Making a World Safe for Organizing', in M-L. Djelic and K. Sahlin-Anderson (eds), Transnational Governance: Institutional Dynamics of Regulation, Cambridge: Cambridge University Press, pp. 31-52.

Fuchs, D., A. Kalfagianni and T. Havinga (2011), 'Actors in Private Food Governance: The Legitimacy of Retail Standards and Multi-Stakeholder Initiatives with Civil Society Participation', Agriculture and Human Values, 28, 353-367.

Grabosky, P.N. (1994), 'Green Markets: Environmental Regulation by the Private Sector', Law \& Policy, 16, 419-448.

Hatanaka, M., C. Bain and L. Busch (2005), 'Third-Party Certification in the Global Agri-food System', Food Policy, 30, 354.

Havinga, T. (2006), 'Private Regulation of Food Safety by Supermarkets', Law \& Policy, 28, 515-533.

Havinga, T. and A. Jettinghoff (1999), 'Self-Regulation in Business: Beyond Associational Self-Regulation', in F. Van Loon and L. Van Aeken (eds), 60 maal recht en 1 maal wijn: Rechtssociologie, Sociale problemen en justitieel beleid, Liber Amicorum prof. dr. Jean Van Houtte, Leuven: Acco, pp. 609-620.

Henson, S. and J. Humphrey (2010), 'Understanding the Complexities of Private Standards in the Global Agri-Food Chains as They Impact Developing Countries', Journal of Development Studies, 46, 1628.

Jacobsson, B. (2000), 'Standardization and Expert Knowledge', in N. Brunnson, B. Jacobsson and Associates (eds), A World of Standards, Oxford: Oxford University Press, p.40.

Kysar, D.A. (2004), 'Preferences for Processes', Harvard Law Review, 118, 525.

Loeber, A., M. Hajer and L. Levidow (2011), 'Agro-Food Crisis: Institutional and Discursive Changes in the Food Scares Era', Science as Culture, 20, 147-155.

Marsden, T., A. Flynn and M. Harrison (2000), Consuming Interests. The Social Provision of Foods, London: UCL Press.

Marsden, T., R. Lee, A. Flynn and S. Thankappan (2010), The New Regulation and Governance of Food. Beyond the Food Crisis?, New York/London: Routledge.

McCabe-Sellers, B.J. and S.E. Beattie (2004), 'Food Safety: Emerging Trends in Foodborne Illness Surveillance and Prevention', Journal of the American Dietetic Association, 104, 1708-1717.

Moran, M. (2002), 'Review Article: Understanding the Regulatory State', British Journal of Political Science, 32, 391.

Van der Meulen, B. (ed.) (2011), Private Food Law. Governing Food Chains through Contract Law, Self-regulation, Private Standards, Audits and Certification Schemes, Wageningen: Wageningen Academic Publishers.

Van Kreyl, C.F. and A.G.A.G. Knaap (eds) (2004), Ons Eten Gemeten. Gezonde Voeding en Veilig Voedsel in Nederland. Houten: Bohn Stafleu Van Loghum.

Vos, E. (2000), 'EU Food Safety Regulation in the Aftermath of the BSE Crisis', Journal of Consumer Policy, 23, 227-255. 